\title{
Erken Dönem Kur'an Tefsirlerine Göre Medine Yahudilerinin Kimlik ve Geleneklerine Genel Bir Bakış*
}

Atıf/C: Yılmaz, Bedriye, (2021). Erken Dönem Kur'an Tefsirlerine Göre Medine Yahudilerinin Kimlik ve Geleneklerine Genel Bir Bakış, Milel ve Nihal, 18 (1), 67-96.

Öz: Kur'an'ın çok sayıdaki sure ve ayetinde, Hz. Muhammed'den önce gelen vahiylere, peygamberlere, onların mensuplarına, gelenekleri ve hatta söylencelerine farklı içeriklerle atıf yapıldığı görülmektedir. Bu makalede Kur'an'da sıklıkla doğrudan muhatap alınmış yahut davranışları ve inançlarıyla konu edilmiş Medineli Yahudiler genel olarak ilgili ayetler ve bu ayetlerin erken döneme (H. 1-2. yüzyıl) ait tefsir rivayetleri bağlamında deskriptif bir yöntemle ele alınmıştır. Buna göre Medine Yahudilerine dair ortaya çıkan tipolojiler üç grupta değerlendirilmiştir. Medine'de yaşayan Yahudilerin kimlik ve geleneklerinin tespitinde tefsir rivayetlerinin derlendiği eserlerin yanı sıra tarih eserleri ve son dönem tarih çalışmalarından istifade edilmiştir. Ayrıca Kur'an'ın Tevrat'a, Yahudilerin ellerinde bulunan kitap(lar)a ve onların geleneğine yönelik atıfları ile erken dönem rivayetlerindeki Tevrat referanslı anlatımların bir kısmı Tanah, Mişna ve Talmud gibi Rabbânî literatürde tespit edilmiştir.

Anahtar Kelimeler: Kur'an, Tefsir rivayetleri, Bağlam, Medine Yahudileri, Rabbânî gelenek, Tevrat, Talmud.

* Makale, yazarın “Medine Yahudileriyle İlişkilerin Erken Dönem Kur'an Tefsirine Etkisi" (Ankara: Ankara Üniversitesi, 2020) başlıklı doktora tezine dayanarak hazırlanmıştır.

** Dr., DiB Bolu İl Müftülüğü, Vaize [byilmazsy@gmail.com] ORCID: 0000-00023571-2548. 
An Overview of Jewish Identities and Traditions in Medina according to Early Qur'an Exegesis

Citation/@: Yılmaz, Bedriye, (2021). An Overview of Jewish Identities and Traditions in Medina according to Early Qur'an Exegesis, Milel ve Nihal, 18 (1), 67-96.

Abstract: Many surahs and verses of the Quran have references with different contents to the revelations, the prophets, their followers, their traditions, and even stories that came before Muhammad. This article deals with the Medinan Jews, who are often directly addressed or sometimes referred to through their behaviors and beliefs in the Quran, in a descriptive method in the context of the related verses and the tafsir narratives of these verses belonging to the early period (A.H. 1st-2nd century). Accordingly, the typologies of Medinan Jews are classified into three groups. In the determination of the identity and traditions of the Jews living in Medina, the main source of this study is tafsir narratives with primary and secondary historical sources. Besides, in this study, the Quran's references to the Torah, book(s) in the hands of the Jews, and their tradition, and some of the Torah-referenced expressions in the early narratives have been identified in Rabbinic literature like Tanakh, Mishnah and Talmud.

Key Words: Qur'an, Tafsir narrations, Context, The Medinan Jews, Rabbinic tradition, Torah, Talmud.

\section{Giriș}

Özde aynı olan vahiy zincirinin son halkası olarak Kur'an önceki vahiylerin metinleri karşısında musaddık olduğunu sıklıkla hatırlatmış, aynı zamanda onların üzerinde muheymin olduğunu belirtmiştir. Kur'an bir yandan önceki vahiyleri tasdik ederken diğer yandan Yahudilerin yanlış inanç ve uygulamalarını tashih etmektedir. Kur'an'ın Medine Yahudileri bağlamında nazil olan ayetlerindeki tasdik, tashih ve tenkit gibi farklılaşan yaklaşımlarının değerlendirilebilmesi, ilgili ayetlerin nüzulüne ait bilgilerin elde edilmesine bağlıdır. Bu bilgileri erken dönem tefsiri, diğer bir ifadeyle tefsir rivayetleri sunmaktadır.

Medine ve çevresinde yoğun nüfusa sahip Yahudi varlığı, ayrıca onların Hz. Muhammed ve Müslümanlarla girdikleri ilişkiler Kur'an vahyine yansımış, ilişkilerin değişen niteliği vahyin dilinde de farklılaşmalara yol açmıştır. Medine' de homojen bir Yahudi topluluğundan söz etmek mümkün olmamakla birlikte baskın Yahudi gruplarının Hz. Muhammed ve Müslümanlara karşı düşmanca tutumlarının yükselen bir ivme göstermesi, onlara karşı vahyin dili ve Hz. Peygamber'in tutumunun sertleşmesine sebep olmuştur. Kur'an bir yandan Medine Yahudilerini tenkit ederken bir yandan 
onlardan istisna ettiği bazılarını övmekte ve kitaplarını tasdik etmeye devam etmektedir. Yahudilerin Müslümanlarla girdiği olumlu-olumsuz ilişkiler, ayetlerde yerilen ve övülen Yahudilerin kimlikleri gibi bilgiler de erken döneme ait tefsir ve tarih rivayetlerinden öğrenilebilmektedir. Böylece ayetlerin bağlamına ait bu bilgiler özelde Yahudiler, genelde Ehl-i Kitap'a dair Kur'an vahyinin doğru anlaşılmasını sağlamaktadır. Örneğin, "ehlu'l-kitâb", "ûtü'lkitâb", "ûtü'l- 'ilm", "ûtû nasîben min el-kitâb" ve "ehlu'z-zikr" gibi Hristiyanları da kapsayan genel ifadelerin kullanıldığı ayetlerin esasen kim(ler) ve hangi olay/olgu bağlamında geldiği bu rivayetlerden öğrenilebilmektedir. Ayrıca Kur'an'ın bazı ayetlerinde açıkça atıf yapılmadığı halde Hıristiyan veya Yahudi bazı grup yahut şahıslardan bahsedildiği tefsir rivayetlerinden öğrenilebilmektedir. Kur'an'ın açı ya da örtülü, kınayıcı ya da takdir edici bir dille atıflarda bulunduğu grup ve/veya şahısların kimlikleri ile bu kimselerin vahye konu teşkil etmelerinin nedenlerini anlayabilmenin, başka bir deyişle ayetleri anlayabilmenin yolu, bu makalede yaptığımız gibi, onları bağlamlarını gözler önüne seren tefsir rivayetleri ile okumaktan geçmektedir. Bağlamsal okuma Kur'an'ın yanı sıra vahiy sürecindeki tarihî anlayabilmenin imkânlarını sunmaktadır.

\section{Medine ve Çevresinde Yahudiler}

Tarihi veriler Hz. Muhammed'e peygamberlik verildiğinde Yahudilerin Arap Yarımadası'nın çeşitli bölge ve şehirlerinde topluluklar halinde yaşadıklarını göstermektedir. Yahudiler, Yemen, Bahreyn, Uman, Fedek, Hayber, Vâdilkurâ, Teymâ, Maknâ, Tâif, Eyle, Cerbâ, Ezruh ve Medine'de yerleşmişlerdir. ${ }^{1}$

Medine, Hicaz bölgesinde Yahudilerin en fazla nüfusa sahip oldukları bir yerleşim olmuştur. Bu nüfusun bir kısmı Yahudiliği sonradan benimsemiş Arap kabilelerinden oluşmakla birlikte belli başlı Yahudi kabilelerinin göç yoluyla geldikleri kabul edilmektedir. Onların şehre ne zaman geldikleri konusunda birkaç rivayete dayanan çeşitli görüşler ileri sürülmüsstür. Yahudilerin Hicaz bölgesine gelişini Hz. Mûsâ dönemine kadar götürenler olduğu gibi MÖ 586'da Assurlular tarafından Kudüs'teki Süleyman mabedinin yıkılışı

1 Ayrıntılı bilgi için bk. Nuh Arslantaş, Hz. Muhammed Döneminde Yahudiler (İstanbul: Kuramer Yay., 2016), 70-105. 
ve/veya MS 70'de Romalılar tarafından ikinci mabedin yıkılışına götürenler de bulunmaktadır. ${ }^{2}$ Bazı rivayetlere göre Yahudilerin Hicaz bölgesine yerleşmelerinde, Tevrat'ta bildirildiği ileri sürülen, bölgeden çıkacak bir peygamberin beklentisi etkili olmuştur. ${ }^{3}$ Yarımadaya gelen Yahudiler arasında kohenlerden ${ }^{4}$ (Hârûnoğulları) bir grup Yesrib (Medine)'e yerleşmiştir. ${ }^{5}$ Semhûdî'ye (ö. 911/1506) göre bu konuda nakledilen rivayetlerden en doğru olanı Yahudilerin Medine'ye Buhtunnasr (Nebukadnatsar) sürgününden sonra yerleştiklerini anlatan rivayettir. ${ }^{6}$ Buna göre Yahudilerin Yesrib'e MÖ 586' da Kudüs'te birinci mabedin yıkılmasıyla geldikleri, ardından MS 70 'de ikinci mabedin yıkılmasıyla yeni bir göç dalgasının yaşandığı söylenebilir.

Mekke'de yerleşik bir Yahudi nüfusundan söz edilmemiştir. Bununla birlikte Mekkeliler Hayber, Yemen ve Şam Yahudileri ile ilişki içerisinde olmuşlar, yaşamlarının belirli dönemlerinde onlardan kitaplar okuyan ve geleceğe dair konuşan bazı kişilerin sözlerini dikkate almışlardır. Mekkelilerin dügün törenlerinde kullanmak üzere Hayber Yahudilerinden eşya kiraladıkları, zaman zaman işlerinde Hayberli kâhinelere başvurdukları ve Hayberli kadınlarla evlilik yaptıklarına dair tarihî bilgiler bulunmaktadır. Bu evliliklerden ikisini Hz. Muhammed'in büyük dedelerinden Hâşim ve kardeşi el-Muttalib yapmıştır. ${ }^{7}$

Gerek araştırmacıların ortaya koydukları bilgiler, gerekse Kur'an'ın bölge Yahudilerine olan hitabı ve onlarla ilgili bahisleri ${ }^{8}$ bölgede İsrailoğulları orijinli Yahudilerin bulunduğu görüşünü

2 Bk. Semhûdî, Vefâu'l-Vefâ bi-Ahbâri Dâri'l-Mustafâ, thk. Kâsım Samerrâ'î (MekkeMedine: Muessesetu'l-Furkân li't-Turâsi'l-İ̇lâmî, 2001), I/293-301.

3 Bk. İbn İshâk, Siyer, çev. Sezai Özel (İstanbul: Akabe Yay., 1991), 134-139; Taberî, Câmiu'l-Beyân an Te'vîli-Âyi'l-Kurân, thk. Abdullâh bin Abdulmuhsin et-Turkî (Kahire: Merkezu'l-Buhûs ve'd-Dirâsâti'l-Arabiyyeti ve'l-İslâmiyyeti, 2001), II/237-241.

4 Kohen: İsrailoğullarına dini konularda rehberlik yapmaları için Rab tarafından seçilmiş olan, Hârûn ve soyundan gelen din adamları sınıfına verilen isimdir. Bk. Çıkış, 28 ve 29. baplar; Joseph Jacobs, "Cohen", The Jewish Encyclopedia (JE), c. IV (New York and London: 1903), 144.

5 Semhûdî, Vefâu'l-Vefâ, I/298.

6 Semhûdî, Vefâu'l-Vefâ, I/297.

7 İbn Sad, Tabakât, I/65, 67, 68-69; Arslantaş, Hz. Muhammed Döneminde Yahudiler, 82-83, 86-87.

8 Örneğin bk. Bakara, 2/40, 41, 47, 50, 72-76, 83, 87, 211, Nisâ, 4/153; Mâide, 5/78-81. 
güçlendirmektedir. Hz. Peygamber Medine'ye hicret ettiğinde oradaki nüfusun büyük çoğunluğunu Yahudi kabileler oluşturmaktadır. Onlar, bir kısmı aslen Yahudi, bir kısmı Arap asıllı olan yirmi civarında Yahudi kabilesidir. ${ }^{9}$ Bunlardan Nadir, Kurayza ve Kurayza'ya bağlı yaşayan Hedl oğullarının Hz. Hârûn'un soyundan gelen kohenler oldukları ${ }^{10}$ Medine'de Buthân köprüsünün yanında yerleşik bulunan Kaynukaoğulları soyunun ise Hz. Yûsuf'a dayandığı belirtilmiştir. ${ }^{11}$ Söz konusu bilgiler ve Kur'an ifadelerinin yanı sıra adı geçen kabilelerin İsrailoğulları'na mensup oldukları, Hz. Peygamber'den aktarılan bazı rivayetlerden de anlaşılmaktadır. Örneğin Hz. Peygamber Yahudi asıllı eşi Safiyye'yi bir olay üzerine teselli ederken "baban Hârûn" ifadesini kullanmıştır. Yine Hz. Peygamber kuşatma sonucu Kurayzaoğulları'na ceza uygulanırken ve Huyey b. Ahtab'ın idamında onlara, başlarına gelenin yaptıkları yüzünden olduğunu söylemiş ve bunu İsrailoğulları'nın Kur'an'da anlatılan benzer durumlarıyla ilişkilendirmiştir. Bu ve benzeri örnekler söz konusu kabilelerin Hz. Peygamber zamanına kadar Yahudi kimliklerini koruduklarına delil gösterilmiştir. ${ }^{12}$

Medine'de Hz. Peygamber'in hicreti öncesinde Arap ve Yahudi kabileleri arasında stratejik ittifaklar yapılmış, bu ittifaklar hicret sonrasında birkaç yıl devam etmiştir. Evs kabilesi Nadiroğulları ve Kurayzaoğulları ile müttefikken, Hazrec kabilesi Kaynukaoğulları ile müttefiktir. ${ }^{13}$ Yahudiler Evs ve Hazrec arasındaki çatışmalara dâhil olmuş, bu çatışmalarda kendi kitaplarının hükmüne aykırı davranarak birbirlerinin de kanını dökmüşler, sonrasında ise kitaplarına uymaya çalışarak fidye karşılığı esirlerini kurtarmışlardır. Bunun üzerine Bakara suresi 84-86. ayetler nazil olmuştur. ${ }^{14} \mathrm{~Hz}$. Peygamber ise Medine'de barış ve güvenliği sağlamaya ve oluşmakta olan Müslüman toplumu korumaya çalışmış, bunun için

\footnotetext{
Semhûdî, Vefâu'l-Vefâ, I/301, 308.

Semhûdî, Vefâu'l-Vefâ, I/178.

Arslantaş, Hz. Muhammed Döneminde Yahudiler, 93.

Bk. Tirmizî, Menâkıb, 63; Arslantaş, Hz. Muhammed Döneminde Yahudiler, 90-91.

Taberî, Câmi 'u'l-Beyân, II/207-208.

Mukâtil, Tefsîr, I/120-121; Taberî, Câmiu'l-Beyân, II/207-215.
} 
"Medine Vesikası" olarak isimlendirilen bir sözleşme de hazırlanmıştır. ${ }^{15} \mathrm{~Hz}$. Peygamber ve Müslümanları tehdit eden ilk Yahudi kabilesi Medine'nin en hareketli pazarına sahip, ekonomi başta olmak üzere birçok yönden güçlü Kaynukaoğulları olmuştur. ${ }^{16}$ Kaynukaoğulları'nın muhasarasıyla ilgili diğer Yahudi kabileleri her hangi bir teşebbüste bulunmazken; onlarla ittifakı olan Hazrec liderlerinden Abdullâh b. Ubey, çıkarlarını korumak adına Hz. Peygamber'e gelip onların gücünden korktuğunu, bu nedenle onlarla olan bağını koparmayacağını bildirip muhasaranın yapılmamasını talep etmiştir. Onun aksine Ubâde b. Sâmit Kaynuka'nın gücüne rağmen onlarla bağını kestiğini ve Hz. Peygamber'in yanında olduğunu bildirmiştir. Bu iki liderin olayla ilgili farklı tutumları sonucu elMâide suresi 51-56 ayetler nazil olmuştur. ${ }^{17} \mathrm{~Hz}$. Peygamber' in hicreti öncesinde Medine'de Yahudiler ilmî yönden de üstün kabul edilmektedir. ${ }^{18}$ Örneğin bazı Arap aileler çeşitli nedenlerle çocuklarını Yahudilere vermişler, Nadiroğulları'nın okullarında Yahudileşen çocuklar kabilenin sürgünü sırasında onlarla birlikte Medine'den ayrılmak istemişlerdir. Çocuklarının şehirden ayrılmasını istemeyen ailelerin Hz. Peygamber'e müracaatı üzerine dinde zorlama olmadığını belirten ayet nazil olmuştur. ${ }^{19}$

\section{Medine'de Yahudi Din Adamları}

Tefsirlere göre Yahudi cemaatinin başındaki kişiler genellikle din adamlarıdır (bilginleridir). Kur'an'da bu bilginlere rabbânîler ve ahbâr olarak atıfta bulunulmuştur. ${ }^{20}$ Mâide suresi 44 . ayet bağlaminda İbn Abbâs (ö.68/687), Mucâhid (ö.103/721), Dahhâk (ö.105/723), Hasen el-Basrî (ö.110/728), Katâde (ö.117/735) ve İbn Zeyd'den (ö.182/798) nakledilen rivayetlerde rabbânîler (الرََّبَّنُُْونَ) ile ahbâr (الأَحْبَارُ (م) hakkındaki tanımlamalara bakıldığında her iki grubun âlim, fakih ve kâri olarak tanımlandıkları, fakat rabbânîlerin üst

15 Bk. Muhammed Hamidullah, İslam Peygamberi, çev. Salih Tŭ̆ (Ankara: Yeni Şafak, 2003), I/190-195.

16 İbn Hişâm, es-Sîretu'n-Nebeviyye, III/9-11; Kaynukaoğulları'nın bu tehdidi üzerine Âli İmrân suresi 12-13. ayetler nazil olmuştur. Taberî, Câmiu'l-Beyân, V/239.

17 Taberî, Câmiu'l-Beyân, VIII/505, 529-530.

18 İbn Kesîr, Tefsîru'l-Kur'âni'l-Azîm, thk. Sâmi b. Muhammed Selâme (Dâru't-Tayyibe, 1999), I/590.

19 Bk. Bakara, 2/256; Taberî, Câmiu'l-Beyân, IV/546-551.

20 Bk. Âli İmrân, 3/79; Mâide, 5/44, 63. 
Erken Dönem Kur’an Tefsirlerine Göre Medine Yahudileri...

düzey öğreticiler, aynı zamanda yöneticiler oldukları görülebilir. ${ }^{21}$ Nitekim zikrettiği rivayetleri değerlendiren Taberî rabbânîlerin insanları yöneten, işlerini yürütüp meselelerini çözen ilim, hikmet ve basiret sahibi kimseler olduklarını söylerken; ahbârın âlimler olduklarını ve onların sorulan meseleler hakkında hüküm (fetva) verdiklerini belirtmiş ve Kab'ul-Ahbâr'1 (ö.32/653) örnek vermiştir. ${ }^{22}$ Suddî'den (ö.127/745) aktarılan rivayete göre Hz. Peygamber'le bilgi alışverişi konusunda sözleşmiş olan İbn Sûriyâ'nın iki oğlundan biri rabbânî, diğeri Hıbr'dır. Rivayetlere göre Hz. Peygamber' in ashabından birkaçı için de rabbânî ifadesi kullanılmıştır. Örneğin İbn Abbâs'ın vefat ettiği gün, "Bugün bu ümmetin rabbânîsi vefat etti" denilmiştir. ${ }^{23}$

Yahudi geleneğinde Tanaim ve Amoraim dönemlerinde (yaklaşık miladi ilk beş yüz yıl) "rabbi/rav" ilim tahsil eden, dini öğreten ve dinle meşgul olan din adamlarına verilen bir unvan iken, "rabban" onları (din öğretmenlerini) yetiştirenler, bir anlamda üst düzey din âlimi ve öğretmenleridir. Yahudi tarihinde iki büyük ekolün kurucusu olan Hilel ve Şamay gibi Yahudi din adamlarından "rabban" olarak bahsedilmiştir. 24 "Hıbr" kelimesi ise İbranice "haver" kelimesini karşılar. Bu kelime milattan önceki asırda Ferisilerden ilim tahsil edenler için kullanılırken, bu mezhebin ortadan kalkmasıyla ilimle meşgul olanlar için kullanılır olmuştur. Talmud'da ise Hârûn'un soyundan gelenler ile Tevrat eğitimiyle meşgul olanlar için kullanılmıştır. ${ }^{25}$ Burada "kâhinân/kohanîm" olarak isimlendirilen kohenlere de değinmek gerekir. Kohen Hz. Hârûn'un soyundan gelenlere verilen bir isimdir. İslam kaynaklarına göre Medine'deki Nadir ve Kurayzaoğulları kabilelerinin bu soydan oldukları kabul edilmektedir. Hz. Muhammed'in eşi Safiyye'nin de kohen ailesine mensup olduğu söylenmiştir. ${ }^{26}$ Kohenler Hz. Mûsâ tarafından dinî hizmetler için seçilmişlerdir. ${ }^{27}$ Kohen olan bir Yahudi sıradan bir

21 Taberî, Câmiu'l-Beyân, VIII/451-454; bk. Salime Leyla Gürkan, "Rabbâniyyûn", DIA, c. XXXIV (2007), 376-377; Osman Cilac1, "Ahbâr", DİA, c. I (1988), 485-486.

22 Taberî, Câmiu'l-Beyân, VIII/451-452.

23 Bk. İbn Ebî Hâtim, Tefsîru'l-Kur'ân'il-Azîm, thk. Es'ad Muhammed Tayyib, (Arabiyyetu's-Suûdiyye, Mektebetü Nezâr Mustafâ el-Bâz, h.1419), IV/1140.

24 Haggai Mazuz, The Religious and Spiritual Life of the Jews of Medina (Leiden-Boston: Brill, 2014), 21-22.

25 Arslantaş, Hz. Muhammed Döneminde Yahudiler, 283-284.

26 Arslantaş, Hz. Muhammed Döneminde Yahudiler, 286.

27 Bk. Çıkış, 28; Levililer, 8:7-9. 
Yahudi'ye göre Tevrat ve Talmud'da belirtilmiş farklı uygulamalara tabidir. ${ }^{28}$

Yukarıda kısmen zikrettiğimiz tefsir rivayetleri ve Yahudi geleneği üzerine yapılan bazı çalışmalardan anladığımıza göre kısaca, rabbi/rav, rabbânî ve hıbr dini ilimlerle farklı seviyede meşgul olan Yahudi bilginlerine verilen unvanlardır. Bunlardan en üst düzeyde olanı rabbânîliktir. Rabbânîler aynı zamanda topluluklarının yöneticileridir. Kohenlik ise daha ziyade soya dayalı bir unvandır. Ayrıca bazı kohenler bilginliğin farklı seviyelerinden birine sahip olabilmektedirler.

Kudüs'e girilmeden önce Kutsal alanın (çadırın), Kudüs'te ise Mabed'in sorumluluğu kohenlere verilmiştir. Onlara toprak yerine, ürün ve takdimelerden (kurban) pay ayrılmıştır. ${ }^{29}$ Kohenler Mabed'in yıkılmasıyla büyük ölçüde etkinliklerini kaybetmişler, zekât olarak isimlendirilebilecek terumadan aldıkları paylar kesilmiş ve cemaatten gelen yardımlarla geçimlerini sağlamışlardır. Kur'an'da el-Bakara suresi 79. ayette küçük dünya menfaatleri karşllığında elleriyle yazdıkları kitabın Allah'tan geldiğini söyleyenlerden söz edilmektedir. Mukâtil b. Suleymân (ö.150/767) ayette kastedilenlerin Yahudi halkının ekinlerinden ve mallarından aldıkları payları kaybetmemek için Hz. Muhammed'in Tevrat'taki nitelikleri yerine başka şeyler yazan Yahudi reisleri olduğunu belirtmiştir. ${ }^{30}$ Söz konusu Yahudi reislerinin halk tarafından kendilerine ürünler verilen kohenler olduğu söylenebilir. ${ }^{31}$ Suddî'den aktarılan bir rivayete göre Yahudilerden bazıları yazdıkları kitapları Allah tarafından gönderildiğini söyleyerek Araplara az bir ücretle satmaktadırlar. ${ }^{32}$ Rivayette sözü edilen kişilerin soferler ${ }^{33}$ yahut topluluk liderleri, yazdıklarının ise "takkanot" adı verilen, topluluklarının gündelik

Bk. Çıkış, 28; Levililer, 9:8-18; 10:10-11; 21:13-15; Talmud Bavli (TB), Ketubot 36a; Gittin 81a.

Tora'yı yazan din adamıdır. Talmud'un emri gereği her cemaatte bulunması zorunludur. Tora ve Tora pasajlarını içeren ibadet nesneleri soferler tarafından yazılır. Bk. Besalel, "Sofer”, “Soferim", Yahudilik Ansiklopedisi (YA), c. III (2002), 631-632. 
sorunlarını çözmeye yönelik fetvalar yahut belirli işlerin düzenlenmesine yönelik yönergeler ${ }^{34}$ olması muhtemeldir. Bunları Tora ve Talmud bilgisine dayanarak hazırladıkları için Allah'tan geldiğini iddia etmiş olabilirler. Belirttiğimiz ayete göre onlar bu iddialarını, yazdıklarını Araplara satarak menfaat elde etmenin bir aracı yapmışlardır. Ayrıca Arapların Medine ve Hayber'de kâhin(e) olarak isimlendirdikleri, çeşitli durumlarda bilgi ve görüş almak için kendilerine başvurdukları bazı Yahudiler bulunmaktadır. Örneğin Hz. Muhammed'in dedesi Abdulmuttalib bir sorununu Hayberli yahut Medineli bir Yahudi kâhineye (arrâfe) danışarak çözmüştür. ${ }^{35}$

Kur'an tefsiri ve İslam tarihi kaynaklarında Medine'deki Yahudi dinî ve siyasî liderlerine sıkça atıf yapılmıştır. Bu isimlerden önemli bir kısmı tefsir rivayetlerini kaydeden eserlerde, özellikle Mukâtil'in tefsirinde çok sayıda ayetin nüzulüne sebep olan kişiler olarak zikredilmiştir. Örneğin Kab b. el-Eşref'in Yahudi liderleri arasında en fazla zikredilen isim olduğu söylenebilir. Onu Nadiroğulları'ndan Huyey b. Ahtab ve kardeşleri Cudey ile Ebû Yâsir takip etmektedir. Ayrıca Mâlik b. ed-Dayf, Kab b. Esîd(Useyd), Saîd b. Amr, Ebû Lubâbe b. Amr, Rifâa b. Zeyd, Finhâs, Râfi b. Hureymile, Zeyd b. Kays, Vehb b. Zeyd ve Numân b. Evfâ da ayetlerin nüzul sebeplerini bildiren tefsir rivayetlerinde zikredilen Yahudilerin önde gelen isimlerindendir. Bu kişiler $\mathrm{Hz}$. Muhammed ve Müslümanlara karşı olumsuz tutumlarıyla öne çıkarken ${ }^{36}$ Müslümanlığ1 kabul eden Kaynukaoğulları'nın âlimi Abdullâh b. Selâm (ö.43/663) birkaç yeğeni ve bazı arkadaşlarıyla birlikte olumlu tutumlarıyla öne çıkmışlardır. ${ }^{37}$ Kur'an ayetleri bağlamında Medine Yahudilerini üç grupta değerlendirdiğimiz kısımda bu isimlere ve nüzulünde etkili oldukları ayetlere değinilecektir.

34 Yusuf Besalel, “Takkanot”, YA, II/692-693.

35 Hamidullah, İslam Peygamberi, I/33, 592.

36 Örneğin bk. Mukâtil, Tefsîr, I/29, 81, 84, 87, 91, 101, 118, 120, 123, 126, 130, 147148, 377-379, 419; II/319; IV/260, 275-276.

37 Örneğin bk. Suyûtî, ed-Durru'l-Mensûr, V/127; Mukâtil, Tefsîr, I/135, 422. 


\section{Tefsir Rivayetlerinde Yahudilere Ait Öne Çıkan Bir Kurum: Bet-Midraş}

Talmud'da Sanhedrin'in ${ }^{38}$ hangi niteliklere sahip şehirlerde kurulacağı, bunun için şehirde bulunması gereken erkek nüfusunun minimum sayısı, hangi kurumların ve hangi meslekten insanların bulunması gerektiği üzerinde durulmuştur. Bir Yahudi bilginin yaşayabileceği şehirde cezaları uygulayabilen yetkili bir mahkeme (bet-din), cemaat içi bir yardımlaşma kurumu, sinagog, hamam, tuvalet, mikve, ${ }^{39}$ sofer, kasap, tabip, okul inşa edebilen usta, çocuk ve gençlerin eğitim görebileceği okulların bulunması gerekmektedir. ${ }^{40}$ Nuh Arslantaş Talmud'da belirtilen her Yahudi topluluğunda bulunması gereken temel kurumlara Arabistan Yahudilerinin de sahip olduğunu ifade etmiştir. ${ }^{41}$ Bir başkan ve iki üyeden oluşan üç kişilik konsil tarafından idare edilen "bet-din" (cemaat evi), bulunduğu bölgedeki Yahudi cemaatinin meseleleriyle ilgilenmiştir. Medine ve Hayber Yahudilerinin bazı meselelerini bet-dinlerinde görüştükleri, Hz. Peygamber'in de ödemeleri gereken bir diyeti talep etmek üzere bir Şabat günü Nadiroğulları'nın cemaat evine gittiği rivayet edilmiştir. ${ }^{42}$

Yahudiler, tefsir rivayetlerinde beytu'l-midrâs olarak zikredilen, bet-midraş isimli eğitim-öğretim kurumlarına sahiptirler. Dini ibadet ve törenlerini de yaptıkları bu okullarda Tevrat, Mişna ve Zebûr okumaktadırlar. İçlerinden suç işleyenleri de burada cezalandırdıkları söylenmiştir. ${ }^{43}$ Gerek Hz. Peygamber'in gerekse Hz. Ebu

38

Üyeleri Yahudi âlimleri ve hâkimlerinden oluşan üst düzey yasama ve yargı kurumudur. Bu kurumda Talmud çalışmaları da yapılmış, bunlar "takkanot" denilen hükümlere temel teşkil etmiştir. Kudüs'teki büyük Sanhedrin 71, diğer şehirlerdekiler 23, en küçük yerleşimlerdeki Bet-dinler ise 3 üyeden oluşmuştur. İkinci Mabed'in yıkılışından sonra yerini Tora, Mişna ve Talmud'un ileri düzeyde çalışıldığı bir tür akademi olan "Yeşiva”lar almıştır. Bu kurum Yahudi hukukunun gelişiminde etkili olmuştur. Artan Roma baskısı sonucu beşinci yüzyılın başlarından itibaren etkinliğini Bâbil'de sürdürmüştür. Bk. Besalel, "Sanhedrin", YA, III/564-566; “Yeşiva", YA, III/783-786.

39 帒içine tam olarak dalınıp çıkılması gereken bir tür havuzdur. Bk. Besalel, "Mikve", YA, II/406-409.

$40 \mathrm{~TB}$, Sanhedrin, $17 \mathrm{~b}$.

41 Arslantaş, Hz. Muhammed Döneminde Yahudiler, 289. Ayrıntılı bilgi için aynı eserin 289-297 sayfa aralığına bakılabilir.

42 Taberî, Câmiu'l-Beyân, VII/144; Vâkıdî, el-Meġâzî, I/364.

43 Taberî, Câmiu'l-Beyân, II/287, 290; Anmet Önkal, "Beytülmidras", DİA, c. IV (İstanbul: 1992), 95. 
Bekr ve Hz. Ömer gibi sahabilerin zaman zaman bet-midraşa giderek orada bulunan Yahudi din adamlarıla konuştukları veya tartıştıkları; bir grup sahabinin de Hayber Yahudileri ile onların betmidraşlarında görüşmeler yaptıklarını anlatan rivayetler bulunmaktadır. ${ }^{44}$ Bunlardan birinde Yahudiler kendilerinden bir kadınla bir erkeğin işlediği zina suçu davasını Hz. Peygamber'e götürmüşler, bunun üzerine Hz. Peygamber Kuff vadisindeki bet-midraşa gitmiş, oradaki Yahudi din âlimlerinden içlerindeki en iyi âlimin Tevrat'la birlikte getirilmesini istemiştir. ${ }^{45}$ Rivayete göre İbn Sûriyâ'nın iki oğlu Hz. Peygambere Tevrat'ın zina konusundaki hükmünü ve hükmün nasıl değiştirildiğini anlatmışlardır. Bunun üzerine Allah "Şüphesiz Tevrat'ı biz indirdik. İçinde bir hidayet, bir nur vardır..." ayetini ${ }^{46}$ indirmiştir. Ayette geçen rabbânîler ve ahbârdan kasıt İ̉nn Sûriyâ'nın bu iki oğludur. ${ }^{47}$

İbn 'Abbâs'tan nakledildiğine göre başka bir zamanda Hz. Peygamber Yahudilerden bir grubun Tevrat okuduğu beytu'l-midrâs'a girip onları Allah yoluna davet ettiğinde, Numân $b$. Amr ve Hâris b. Zeyd "Ey Muhammed! Sen hangi din üzeresin?" diye sormuşlar, o "İbrâhim'in milleti ve dini üzereyim" karşıllğını vermiş, onlar "İbrâhim bir Yahudiydi" dediklerinde Hz. Peygamber onlara "o zaman Tevrat'a bakalım o aramızı bulur" demiştir. Fakat orada bulunan Yahudiler bunu kabul etmemiş ve Allah Âli İmrân suresi 23. ayeti inzal etmiştir. ${ }^{48}$

Hz. Peygamber'in talimatıyla Zeyd b. Sâbit'in (ö.45/665) İbranice öğrendiği yerin Medine'nin Kuff vadisindeki bet-midraş olduğu belirtilmiştir. ${ }^{49} \mathrm{~Hz}$. Ömer'in de Kuff yakınlarındaki tarlasına gidip gelirken sık sık bet-midraşa uğrayıp oradaki Yahudi din bilginleriyle sohbet ettiği ve tartıştığ 1 rivayet edilmiştir. ${ }^{50}$ Yahudilerin her cemaat için en az bir bet-midraşın olması teamülünden hareketle Medine'de birden fazla bet-midraş olduğu üzerinde durulmuştur. ${ }^{51}$

\footnotetext{
Bk. Taberî, Câmiu'l-Beyân, II/287, 290; VIII/414-415, 425-426.

Taberî, Câmiu'l-Beyân, VIII/450-451.

Mâ'ide, 5/44.

Taberî, Câmiu'l-Beyân, VIII/452-453.

Taberî, Câmiu'l-Beyân, V/293-294.

Bk. Arslantaş, Hz. Muhammed Döneminde Yahudiler, 296.

Bk. Taberî, Câmiu'l-Beyân, II/287-291.

Arslantaş, Hz. Muhammed Döneminde Yahudiler, 296-297.
} 
Bet-midraşta öğretmenlik yapanlar arasında İbn Sûriyâ, Ebû Yâsir b. Ahtab ve Vehb b. Yahûda gibi din âlimleri bulunmaktadır. ${ }^{52}$ İbn Sûriyâ'nın biri rabbânî, diğeri Hıbr olan iki oğlu da öğretmenler arasındadır. Ayrıca o ikisi Hz. Peygamber'le bilgi alışverişinde bulunmak üzere sözleşmişlerdir. ${ }^{53}$ Kaynukaoğulları'dan bir Yahudi iken Müslüman olan Abdullâh b. Selâm'ın babasından Tevrat ve Talmud öğrendiği ve bet-midraşta rabbi olarak görev yaptığı nakledilmiştir. ${ }^{54}$

\section{Medine Yahudilerinin Ellerinde Bulunan Kitap(lar): Tevrat ve Kapsamı}

Tek tanrı inancına sahip Yahudiler için Tevrat her şeyden önemlidir. Onlara göre Tevrat ve İsrail kâinattan önce yaratılmıştır, kendilerine ilim ve her şey olarak niteledikleri Tevrat verilmiştir. ${ }^{55}$

Medineli Yahudilerin ellerinde "tomar" ve "mushaf" olarak Tevrat bulunmakta ve bunları bet-midraşlarda okumaktadırlar. ${ }^{56}$ Nitekim Kur'an zaman zaman Yahudilerin ellerindeki kitabı çeşitli konularda şahit tutmakta, hatta Hz. Peygamber'e Tevrat'1 getirip okumalarını söylemesini buyurmaktadır. ${ }^{57}$ Suddî'den rivayet edildiğine göre Yahudiler çocuklarına oldukça küçük yaşlarda Tevrat öğretmeye başlamakta, bundan dolayı da kendi günahlarının hafifletileceğine inanmaktadırlar. Abdullâh $b$. Selâm ve Zubeyr b. Bâtâ'nın (ö.3/625) Tevrat öğrenimlerini babalarından aldıkları nakledilmiştir. ${ }^{58}$ Bazı rivayetlere dayanarak Medine Yahudileri içerisinde Tora, Tefillin ${ }^{59}$ ve Mezuza'ların ${ }^{60}$ istinsahını yapan soferlerin

52 Mukâtil, Tefsîr , I/476.

53 Taberî, Câmiu'l-Beyân, VIII/452.

54 Samuel b. Yahya el-Mağribî, Yahudiliği Anlamak, trc. Osman Cilacı (İnsan Yay., İstanbul 1995), 107; Mustafa Fayda, “Abdullâh b. Selâm ”, DIA, c. I (1988), 135.

55 Baki Adam, "Tevrat", DIA, c. XLI (2012): 41; Ömer Faruk Harman, "Yahudilik", DIA, c. XLIII (2013), 206.

56 Bk. Taberî, Câmiu'l-Beyân, VIII/414-415; Arslantaş, Hz. Muhammed Döneminde Yahudiler, s. 356.

57 Âli İmrân: 3/93.

58 Bk. İbn Sad, Tabakât, I/133; Arslantaş, Hz. Muhammed Döneminde Yahudiler, 295.

59 İçinde Tora pasajları bulunan, Cumartesi ve bayram günleri haricinde her sabah duasında biri kola diğeri başa takılan deri kutucuklardır. Besalel, "Tefillin", YA, III/728-730.

$60 \quad$ שמע ישראל: יהוה אלהינו יהוה אחד /'Şema Yisrael: Yhoh Eloheynu Yhvh Ehad/Dinle Israil: Aşem Tanrımızdır, Aşem Bir'dir' (Tesniye, 6:4) Tora pasajının yazılmış olduğu, bir 
bulunduğu belirtilmiştir. Tevrat tomar ya da mushaflarının betmidraş veya sinagoglar dışında bazı Yahudilerin evlerinde de bulunduğu söylenebilir. ${ }^{61}$ Örneğin Hz. Peygamber Hayber fethinin ganimetleri arasında bulunan Tevrat mushaflarını talepleri üzerine Yahudilere iade etmiştir. ${ }^{62}$ Medine Yahudilerinin önde gelen din adamlarından Zubeyr'in babası Bâtâ'nın Tevrat müstensihi olduğu anlaşılmaktadır. Rivayete göre Nadiroğulları'nın Medine'den sürülmesinin ardından gelişmeleri görüşmek üzere toplanan Kurayzaoğulları'na Zubeyr şöyle bir itirafta bulunmuştur: “...Tevrat'a yemin olsun ki ben o peygamberin sıfatını Mûsâ'ya nâzil olan ve babam Bâtâ tarafından istinsah edilen Tevrat'ta okumuştum." 63

Medine'de Tevrat bilgisine sahip olmayan, Tevrat'ı okuyamayan Yahudiler de bulunmaktadır. Kur'an'ın bildirdiğine göre Tevrat'1 bilenler bu kesimden Tevrat'ta bulunan bazı bilgileri gizlemektedirler. ${ }^{64}$ Gizlediklerinin başında Hz. Muhammed'in peygamberliği ve Kâbe'nin kıble olduğu bilgileri gelmektedir. ${ }^{65}$

Hz. Muhammed'in Yahudilerin Medine'deki bet-midraşına ziyarette bulunduğu bir seferinde onlara hukuki bir konuda Tevrat'ta geçen hükmü sorduğu, bunun üzerine Yahudilerin Tevrat'ı önüne getirip açtıkları rivayet edilmiştir. Tevrat kendisine getirildiğinde Hz. Muhammed, saygisindan olsa gerek, altındaki minderi kucağına alıp Tevrat'ı üzerine koymuş, "sana ve seni gönderene inandım" demiştir. ${ }^{66}$ Ayrıca Hz. Peygamber'in Tevrat okuyan Yahudileri dinlediği; ${ }^{67}$ bazı Yahudilerin de Kur'an okurken Hz. Peygamber'i dinlediği nakledilmiştir. ${ }^{68}$

kılıfla kaplanmış, evlerin kapı pervazlarının sağ üstüne monte edilen nesnedir.

Besalel, "Mezuza", YA, II/403-404.

Arslantaş, Hz. Muhammed Döneminde Yahudiler, 293.

Vâkıdî, el-Megâzî, II/680-681.

İbn Sad, Tabakât, I/133.

Bk. Bakara, 2/78.

Taberî, Câmiu'l-Beyân, II/670-673; Mukâtil, Tefsîr, I/147-148.

İbn Kesîr, Tefsîr, III/114.

Ahmed b. Hanbel, Musned, I/416.

Suyûtî, ed-Durru'l-Mensûr, XIII/175-177; Mukâtil, Tefsîr, II/319. 
Hz. Ömer'in bet-midraş ziyaretlerinden birinde Tevrat'la ilgili olarak “Tevrat'ın Furkân'ı (Kur'an) Furkân'ın da Tevrat'i doğrulamasını seviyorum" dediği aktarılmıştır. ${ }^{99}$ Abdullâh b. Sâbit'ten aktarılan bir rivayete göre Hz. Ömer Hz. Peygamber'e gelerek Kurayzaoğulları'ndan bir kardeşine uğradığını ve onun kendisine Tevrat'tan bazı veciz sözler yazarak verdiğini söylemiş ve elindeki sahifeyi göstermek istemiştir. ${ }^{70}$ Sahabeden bazıları da Yahudilerin söylediklerinden bazı şeyler yazıp Hz. Peygamber'e getirmişlerdir. ${ }^{71} \mathrm{Bu}$ rivayetlere göre $\mathrm{Hz}$. Peygamber Hz. Ömer' in ve sahabilerin davranışlarını onaylamamıştır. Hz. Peygamber'in Tevrat'a saygı duyup, hükmünü uygulamasıyla sahabeye gösterdiği bu tepki çelişkili gibi görünse de bunun, sahabenin ellerindeki metinleri kimlerden aldıkları, yazının gelişmemiş olmasından kaynaklanabilecek yanlışlıklar ve bu tip bir davranışın yaygınlaşmasının yol açabileceği sorunlar gibi nedenlere bağlı bir tutum olduğu düşünülmektedir. Zira Hz. Peygamber'den İsrailoğulları'ndan nakilde bulunmakta bir sakınca olmadığını belirttiği rivayetler de nakledilmiştir. ${ }^{72}$

Okuryazar Medine Yahudilerinin Tevrat'1 İbranice okuyup Müslümanlar için Arapça tefsir ettikleri Ebû Hureyre' den (ö.58/678) nakledilmiştir. ${ }^{73}$ Bilinen Arapçaya tercüme edilmiş ilk Tevrat Sura Akademisi başkanı, İslam dünyasında Saîd b. Yûsuf el-Feyyûmî olarak bilinen, Saadiya Gaon'a (ö.330/942) aittir. ${ }^{74}$ Bundan önce Tevrat'ın tümünün Arapçaya tercüme edilip edilmediği hususunda farklı görüşler bulunmaktadır. Abbasiler döneminden itibaren kapsamlı ve sistemli Arapça Kitab-1 Mukaddes tercümelerinin yapıldığ 1 üzerinde durulmuş, 128/750 yılında Endülüs Yahudilerinin istifadesi için tam bir Tevrat tercümesi yapıldığı belirtilmiştir. ${ }^{75}$ Ayrıca

69 Taberî, Câmiu'l-Beyân, II/287.

70 Suyûtî, ed-Durru'l-Mensûr, III/648.

71 Taberî, Tefsir, XVIII/429.

72 Bk. M. J. Kister, “Haddithû 'an banî İsrâ'̂̂la wa-lâ haraja”, Israel Oriental Studies II (Tel Aviv University, 1972): 215-239.

73 Buhârî, Tefsîr, 11.

74 Eser Yahudi Arapçası (Judaeo-Arabic)'ndan Türkçe'ye tercüme edilerek yayımlanmıştır. Bk. Saadya Gaon, Tefsîru't-Tevrât bi'1 Arabiyye: Tevrat (Tora) Tefsiri, 2 c., haz. Nuh Arslantaş (İstanbul: Türkiye Yazma Eserler Kurumu Başkanlığı, 2018).

75 Ertuğrul Döner, Tefsirde İsrâiliyyât'ın Kaynak ve Bilgi Değgeri (Ankara: Ankara Okulu Yay., 2017), 202-203. 
Erken Dönem Kur'an Tefsirlerine Göre Medine Yahudileri.. .

es-Sîre'sinde Tevrat ve İncil'den nakiller yapan İbn İshâk'ın (ö. 151/768) elinde de Arapça bir Kitab-1 Mukaddes'in bulunduğu üzerinde durulmuştur. ${ }^{76}$ Bunun dışında çalışma dönemimize ait Medine'de veya Arap Yarımadası'nda Tevrat'ın bütününün Arapça tercümesinin olup olmadığı hakkında kesin bir bilgi bulunmamakla birlikte bu konuda birbirinden farklı görüşler ortaya konulmuştur. ${ }^{77}$

Medine ve çevresinde yaşayan Yahudilerin, dolayısıyla Müslümanların "Tevrat" ile hangi kitap ya da kitapları kastettikleri, diğer bir deyişle "ellerinde bulunan" metinlerin neye/nelere karşılık geldiği üzerinde durmak gerekir. Rivayetlerden elde ettiğimiz bilgilere göre Yahudi bilginlerin elinde kısmen de olsa Mişna, Talmud ve Midraşlar gibi Rabbânî Yahudi geleneğine ait metinlerin bulunduğu söylenebilir. Ayrıca söz konusu geleneğe ait bazı halahik ve agadik bilgilerin sözlü kültür içerisinde dolaşımda olup uygulandığı ve bölge Yahudileri ile Müslümanların bu geleneğe ait yazılı ve sözlü kaynakları "Tevrat" olarak nitelediklerini söyleyebiliriz.78 Ayrıca Kur'an'da vahiy olduğu belirtilerek atıf yapılan bazı içerikler mevcut Tora, Tanah ya da Mişna ve Talmud içerisinde bulunabilmektedir. Örneğin Mâide suresi 41-50. ayetlerde Medine Yahudilerinden bir grubun öldürme ve zinanın Tevrat'taki cezaî hükümlerini uygulamamak için hakem olarak Hz. Muhammed'e başvurmaları konu edilmiş, 45. ayette kısas hükmünün Tevrat'ta yazdığı haber verilmiştir. Zina davasıyla ilgili olarak Hz. Peygamber'in bu konudaki Tevrat hükmünün recm olduğunu öğrenip uyguladığı da tefsir rivayetlerinden öğrenilmektedir. Kur'an'da Tevrat'ta yazdığı belirtilen kısas hükmünün yanı sıra aynı ayetlerin tefsirlerinde belirtilen recm hükmü günümüzdeki Tora içerisinde bulunmaktadır. ${ }^{79}$ Andolsun biz Zikr'den sonra Zebûr'da da yere salih kullarımın varis olacağını

76 Josef Horovitz, İslami Tarihçiliğin Doğuşu, çev. Ramazan Altınay, Ramazan Özmen (Ankara: Ankara Okulu Yay., 2002), 84.

77 Bk. Döner, Tefsirde İsrâiliyyât'ın Kaynak ve Bilgi Değeri, 199-204.

78 Taberî, Câmi 'u'l-Beyân, X/491-492; İbn Kesîr, Tefsîr, III/486.

79 Çıkış, 21: 12-14, 23-25; Levililer, 20: 10; 24: 17, 19-20; Sayılar, 35: 30-31; Tesniye, 22: 22-24. 
yazdık ${ }^{80}$ ayeti, Tora ve Mezmurlar'da adalette devamlı ve dürüst sadıklar ile mütevazı olanlarn yere varis olacaklar1 ${ }^{81}$ bilgisiyle yer almaktadır. Ayetteki "zikr"in Tora'ya karşılık gelmesi muhtemeldir. Nitekim tefsir rivayetleri arasında bu görüş de yer almaktadır. ${ }^{82}$

Mâide suresi 32. ayette Allah İsrailoğulları'na Kim, bir insanı, bir can karşılığı veya yeryüzünde bir bozgunculuk çıkarmak karşılığı olmaksızın öldürürse, o sanki bütün insanları öldürmüştür. Her kim de birini yaşatırsa, sanki bütün insanları yaşatmıştır yazdığını buyurmuş, bazı tefsir rivayetlerinde bu hükmün Tevrat'ta yazdığı belirtilmiştir. $\mathrm{Bu}$ ayet mevcut Tora'da değil, hemen hemen aynı ifadelerle Mişna' da bulunmaktadır. ${ }^{83}$ Bu da Kur'an'ın Medine ve çevresindeki Rabbânî Yahudileri muhatap aldığını ve döneme ait "Tevrat" alg1sının sözlü Tevrat kabul edilen Rabbânî literatürü de kapsadığını göstermektedir. Zira Rabbânî Yahudilikte Mişna ve Gemara'dan oluşan Talmud vahye dayalı kabul edilmekte ve "Sözlü Tora" olarak nitelenmektedir. ${ }^{84}$

Tefsir rivayetlerine göre ...o mescidde temiz olmayı sevenler vardır. Allah da temiz olanları sever ${ }^{85}$ ayetinde kastedilenler Medine'nin Kubâ Mahallesi'nde oturan Müslümanlardır. Hz. Peygamber'in uyguladıkları temizliğin mahiyetine dair kendilerine yönelttiği soruyu su ile taharetlenmek olarak cevaplayıp, bunu da Yahudi komşularından öğrendiklerini belirtmişlerdir. Ayette övülen Kubâlı Müslümanlardan bazllarının Hz. Peygamber'e daha önce Yahudi dinine bağlı olup Tevrat'ın emri gereği suyla taharetlendiklerini, Müslüman olduktan sonra da buna devam ettiklerini söyledikleri de aktarılmıştır. Tüm rivayetlerde Hz. Peygamber ayette övülenlerin bu temizliği yapanlar olduklarını belirtmiştir. ${ }^{86}$ Tuvalette suyla taharet doğrudan mevcut Tevrat'ta bulunmamaktadır. Onların Talmud gibi metinleri yahut dine içkin geleneği "Tevrat" olarak tanımladıkları düşünülmektedir. ${ }^{87}$ Nitekim Mişna ve Talmud'un altı kitabından

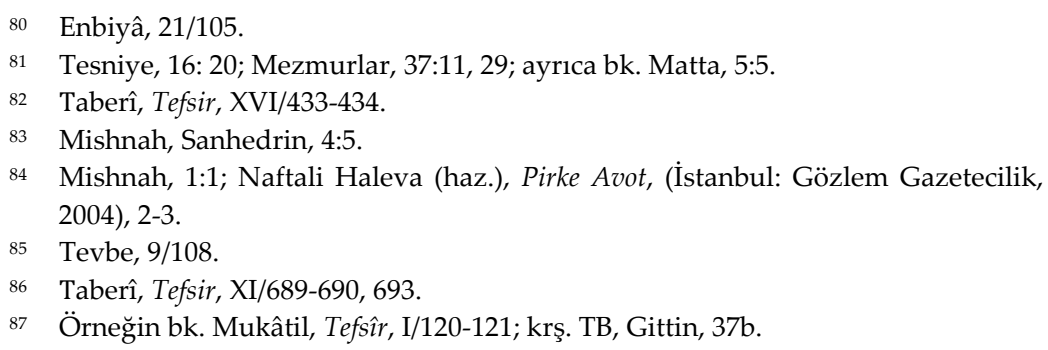


biri “Taharot (Temizlenme)"dur. Talmud'da diğer beş kitabın bölümleri altında da temizlik konulu pasajlar yer almaktadır. Örneğin Zeraim kitabının en geniş bölümü Berakhot'ta tuvalet adâbı, bazı ibadetlerden önce tuvalet ihtiyacının giderilip ellerin yıkanması hükmü, su bulunamadığı takdirde teyemmüm edilmesinin gerekliliği gibi uygulamalar öğretilmektedir. ${ }^{88}$

\section{Arap Kültürüyle Harmanlanmış Rabbânî Gelenek}

Günlük hayatta Arapçayı kullanan Arabistan Yahudilerinin, ibadetlerinde ve diğer dini ritüellerinde İbraniceyi kullandıkları, İbraniceyi çocuklarına da öğretmeye çalıştıkları belirtilmiştir. Ayrıca Arapçayı zaman zaman İbrani alfabesi ile yazdıkları da ifade edilmiştir. ${ }^{89}$ İbranice okudukları Tevrat'1 Müslümanlar için Arapça tefsir ettiklerine değinilmişti. ${ }^{90}$ Bölgedeki Araplar Yahudilerden dini ve kültürel açıdan etkilenirken, ${ }^{91}$ Yahudilerin de Arapların dil ve kültüründen etkilendiğini, etkileşimin karşılıklı olduğunu söylemek gerekir. Kanaatimizce Medine ve çevresinde yaşayan Yahudilerin Arapça konuşmaları, Arap isimleri almaları ya da Araplar gibi giyinmeleri onların Araplaştığını göstermez. Esasen bu kültürel uyum Rabbânî Yahudiliğin bir gereğidir. ${ }^{92}$ Medine' deki dört kabile ve Hayber dışındaki Yahudi kabilelerinin büyük çoğunluğu ise Yahudileşen Araplardan oluşmaktadır.

Medine Yahudilerinin Bizans ve Sasani devletlerinde yaşayan Yahudiler gibi organize bir cemaat yapısına sahip oldukları, söz konusu coğrafyalarda bulunan Yahudiliğin merkezleri Bâbil ve Filistin okullarıyla irtibat halinde bulundukları çeşitli kaynaklara dayanılarak dile getirilmiştir. ${ }^{93}$ Örneğin Rabbânî Yahudiliğin ikinci temel kaynağı olan Talmud'da belirtilen hüküm, tavsiye ve uygulamalardan bir kısmının Medine, Hayber ve Vâdilkurâ gibi şehirlerde yaşayan Yahudiler tarafından dikkate alınıp uygulandığı ortaya konulmuştur. ${ }^{94}$ Bunlar arasında abdest, gusül, teyemmüm, tuvalet

Bk. TB, Berakhot, 15a; 23a; Berakhot, 61b-62a.

Hamidullah, İslam Peygamberi, I/187, 570.

Buhârî, Tefsîr, 11.

İbn Kesîr, Tefsîr, I/590.

Besalel, "Minhag", YA, II/409.

Arslantaş, Hz. Muhammed Döneminde Yahudiler, 279-280, 393-399.

Bk. Mazuz, The Religious and Spiritual Life of the Jews of Medina, 74-75; Arslantaş,

Hz. Muhammed Döneminde Yahudiler, 279-282, 393-399.
} 
adabı, ${ }^{95}$ namaz, zekât, sadaka; ${ }^{96}$ evlilik, ${ }^{97}$ eşler arası ilişki ${ }^{98}$ gibi birçok pratik sayılabilir. Bunlardan bir kısmının uygulanışı tarihsel süreç içerisinde değişikliğe uğramış veya ortadan kalkmıştır. ${ }^{99}$ Mehmet Paçacı Kur'an'dan önceki kitaplara dayanan uygulamalardan oluşan bir geleneğin Kur'an'ın indiği vasatta mevcut olduğu ve Kur'an vahyinin bu uygulamaları meşru kabul ettiğini belirtmektedir. ${ }^{100}$ Kur'an'ın bu kabulü doğal olarak Hz. Peygamber ve onu takip edenlerin uygulamalarına yansımıştır. Örneğin Hz. Peygamber kıble olarak Kudüs'e yönelmiş, ${ }^{101}$ bazı evlilerin zinasını Tevrat'ta geçtiği gibi recm ile cezalandırmış, ${ }^{102}$ çok sayıda kadınla evliliği dört ile sinırlandırmıştır. ${ }^{103} \mathrm{Bu}$ uygulamasıyla onun ilgili Kur'an ayetini ${ }^{104}$ Talmud geleneğine ait içtihatla tefsir etmiş olduğu düşünülebilir. ${ }^{105}$

Medine Yahudileri peygamberlere ve meleklere iman etmekte, fakat İbrani saymadıkları peygamberleri kabul etmedikleri gibi melekler konusunda da kısmen farklı görüşlere sahip oldukları bilinmektedir. Onlardan bazıları Mikâil'i sevip Cebrâil'i sevmediklerini belirterek bunu Hz. Muhammed'e iman etmemelerine bahane göstermişlerdir. ${ }^{106}$

Bazı rivayetlerde İslam'ın doğuşuna yakın zamanlarda peygamberin çıkacağına dair bir inançla Hicaz bölgesine gelip yerleşen

Bk. Abraham Isaac Katsh, Judaism in Islam: Biblical and Talmudic Backgrounds of the Koran and Its Commentaries (New York University Press, 1954), 8-9, 12-13.

Bk. Mishnah, Yevamoth, 4: 10; TB, Yevamot, 41a, 42a-b.

Bk. TB, Nedarim 20a-20b.

Katsh, Talmudik çalışmaların Arabistan Yahudilerinin günde beş kez ibadet ettiğini ortaya koyduğunu belirtmektedir. Bunlar günde üç kez düzenli yapılan ibadet ile sabah ve akşam yapılan shema duasının toplamıdır. Katsh Hz. Muhammed'in birçok Yahudi dini pratiğini olduğu gibi bu pratiği de örnek aldığını iddia etmiştir. Bk. Katsh, Judaism in Islam, 6-11.

Mehmet Paçacı, "Kur'an'ın Neliğine Dair", Çă̆daş Dönemde Kur'an'a ve Tefsire Ne Oldu (İstanbul: Klasik Yay., 2008), 151-152.

Taberî, Câmiu'l-Beyân, II, 622-623.

Bk. Taberî, Câmiu'l-Beyân, VIII/417-418, 425-426, 450-451; Levililer, 20: 10; Tesniye, 22: 23-24.

İbn Kesîr, Tefsîr, II/209, 211; Mukâtil, Tefsîr, I/356-357.

Nisâ, $4 / 3$.

Bk. Mishnah, Ketuboth 10: 1-6; TB Yevamot 44a; Mehmet Paçacı, "Bir Yorum Eleştirisi: Çağdaşçı Kur'an Yorumu Üzerine”, Çă̆daş Dönemde Kur'an'a ve Tefsire Ne Oldu ?, 82.

Bo6 Bakara, 2/97; Taberî, Câmiu'l-Beyân, II/287-291. 
Yahudilerden söz edilmektedir. Buna rağmen Medine Yahudilerinin çoğu Hz. Muhammed'i kabullenmemişlerdir. Oysa Evs ve Hazrec kabilelerinin Hz. Muhammed'in peygamberliğini kabullenişlerinde bu inancın etkisinden söz edilmiştir. el-Bakara suresi 89. ayet bağlamında Yahudilerin, beklenen peygamberin bir kitap getireceğine ve ataları İbrâhim'in dinini izleyeceğine inandıkları, ayrıca Ahmed ismini taşıyacak olan bu mesihin müşriklere karşı kendilerine yardım edeceğini kabul ettiklerine dair rivayetler mevcuttur. ${ }^{107}$ İbn İshâk' in zikrettiği rivayetlerden birinde Şam Yahudilerinden İbnu'l-Heybân adında birinden bahsedilmiştir. Bu adam, Şam'ın bereketli topraklarından kurak Hicaz'a peygamber beklentisiyle gelip yerleşmiştir. $\mathrm{O}$, beş vakit namazı herkesten iyi kılan, kıtlık zamanlarında ahaliyle yağmur duası yapan, dua ettiğinde yağmurun yağdığı, ölüm anı yaklaştığında bölge Yahudilerini toplayıp onlara gelecek olan peygambere tabi olmalarını vasiyet eden biri olarak tanitılmıştır. ${ }^{108}$

Tanrı' nın has kulları olarak sadece kendilerini gören seçilmişlik inancı Medine Yahudilerinde de görülmektedir. Kur'an İsrailoğulları'nın âlemlere üstün kılındığını bildirmiş, ${ }^{109}$ fakat tefsirlerde bu üstünlük Hz. Mûsâ dönemi tarihselliği içerisinde değerlendirilmiştir. ${ }^{110}$ Kur'an'da Medine Yahudilerinden bu inanca sarılip Hz. Muhammed ve Müslümanlara karşı üstünlük taslayanlar uyarılmıştır. ${ }^{111}$ Ayrıca ahiret ${ }^{112}$, kiyamet ve hatta kabir sorgusu ve azabına dair de inançları bulunmaktadır. ${ }^{113}$ Kur'an'daki pek çok ayet bölge Yahudilerinin Tanrı, Tevrat, Peygamber, melek, kıyamet ve ahiret gibi temel inançları arasında yer alan yanlışlık veya tutarsizlıkların tashihi ve onların Hz. Muhammed ile sahabeye bu konularda sorular sormaları gibi çeşitli vesilelerle gelmiştir. ${ }^{114}$

\footnotetext{
107 Bk. Taberî, Câmiu'l-Beyân, II/237-241; İbn İshâk, Siyer, 134-139.

108 İbn İshâk, Siyer, 138.

109 Bakara, 2/47, 122.

110 Taberî, Câmiu'l-Beyân, I/629-630; II/496-497.

111 Bakara, 2/80, 94; Nisâ, 4/49-50; Mâide, 5/18.

112 Bk. Mehmet Paçacı, Kutsal Kitaplarda Ölüm Ötesi (Ankara: Ankara Okulu Yay., 2001).

113 Bk. Taberî, Câmiu'l-Beyân, II/237-241.

114 Bk. Bakara, 2/47, 48, 51, 54; 75-77, 80, 83, 88-94, 97, 99-100, 102, 122, 123, 132-135, 144, 183, 186; 256; Âli İmrân, 3/64, 77; Nisâ, 4/46, 49-51, 123, 153; Mâide, 5/12, 13, 18, 41-50, 58, 60; Enâm, 6/19-20, 91; A'raf, 7/140, 163, 187; Tevbe, 9/30-31; Kehf,
} 


\section{Kur'an Ayetleri Bağlamında Üç Grupta Medine Yahudileri}

İlk grup Kab b. el-Eşref, Huyey b. Ahtab gibi Yahudi kabilelerinin liderleri vasfındaki kişilerden oluşmaktadır. Onlar Tevrat'ı iyi bilmekte fakat şehirde sahip oldukları gücü ve etkinlik alanını kaybetmek istememektedirler. Bu nedenle Müslümanların yükselişini kabul edememiş ve kendilerine rakip olarak gördükleri bu gücü kırmak için Hz. Muhammed'e düşmanlık eden müşriklerle müttefik olup onunla anlaşmalarını bozmuşlar, birçok durumda kendi kitaplarına da uymamışlardır. Müslüman-Yahudi ilişkilerinde gerilimi tırmandıran bu grup vahiy süreci boyunca gündemde olmuş, Yahudilere ilişkin çoğu ayet onların eylemleri bağlamında gelmiştir. ${ }^{115}$ Tefsir rivayetlerine göre bu ayetlerde sözü edilen Yahudilerin başında Kab b. el-Eşref ve Huyey b. Ahtab, yanı sıra Huyey'in kardeşleri Cudey ve Ebû Yâsir, Mâlik b. ed-Dayf, Kab b. Esîd (Useyd), Saîd b. Amr, Ebû Lubâbe b. Amr, Rifâa b. Zeyd, Finhâs b. Azura, Râfi b. Hureymile, Zeyd b. Kays, Vehb b. Zeyd ve Numân b. Evfâ'nın isimleri geçmektedir. ${ }^{116}$

Mekke'de nâzil olan bazı sure ve ayetlerin nüzulünde Medine'de yaşayan Yahudilerin etkisinden söz edilmektedir. Yahudilerden bazıları Mekke'ye gelerek yahut Kureyşliler aracilığıyla Hz. Peygamber'e bazı sorular yöneltmişler, İhlâs ve Yûsuf suresinin tamamı ile Kehf ve İsrâ surelerinin bazı ayetleri nâzil olmuştur. Örneğin Mekkeli müşrikler Medineli Yahudilerin isteğiyle $\mathrm{Hz}$. Peygamber'e Şam(Filistin) bölgesinde yaşayan, Mısır'a giden oğlunun ayrılık acısına dayanamayıp gözleri kör olan peygamberi sormuşlar, bunun üzerine Yûsuf suresi tek seferde nâzil olmuştur. ${ }^{117}$ Surenin hicretten önce Medine'ye giden bazı sahabe, hicretten sonra Hz. Peygamber tarafından Medine'de okunduğu, onun tilavetini dinleyen Yahudilerden biri âlim olan birkaç kişinin Müslüman oldukları söylenmiştir. ${ }^{118}$ Mukâtil'in bildirdiğine göre aralarında Kâb

18/109; Meryem, 19/55, 59; Tâ Hâ, 20/91; Enbiyâ, 21/73; Saffât, 37/158; Zümer, 39/67; Müddessir, 74/30-31; İhlâs/112.

115 Örneğin bk. Bakara, 2/1-7, 14, 41-47, 75-76, 79, 91, 97-101, 105, 108-109, 118, 143; Âli İmrân, 3/1-4, 7; 118-119; Nisâ, 4/44-47; 51-55; 60-61; 153; Mâide, 5/11, 43-44, 46, 48; Nûr, 24/47-52; Mucâdele, 58/8.

116 Bk. Mukâtil, Tefsîr, I/91, 101, 118, 123, 126, 130, 377-379, 419; II/319; IV/260, 275276.

117 Suyûtî, ed-Durru'l-Mensûr, XIII/175.

118 Suyûtî, ed-Durru'l-Mensûr, XIII/175-177. 
Erken Dönem Kur'an Tefsirlerine Göre Medine Yahudileri...

b. el-Eşref, Ahtab'ın oğulları Huyey ve Cudey, Mâlik b. ed-Dayf'ın da bulunduğu bazı Yahudiler de Hz. Peygamber'in Yûsuf'u anlatışını duymuşlar, fakat fakir birkaç Yahudi dışında Hz. Peygamber'e iman eden çıkmamıştır. ${ }^{119}$

Medine' de hicretin birinci yılında nâzil olan el-Bakara suresinin ilk yüz ayeti İbn Abbâs'tan nakledildiğine göre Yahudilerin ahbârı ile Evs ve Hazrec kabilelerinden münafıklarla ilgilidir. ${ }^{120} \mathrm{~Hz}$. Peygamber Yahudi ileri gelenlerinden bazıların İslam'a davet ettiğinde onların "Allah Mûsâ'dan sonra kitap indirmedi" demeleri üzerine surenin ilk ayetleri nâzil olmuştur. Dört ve beşinci ayetlerde Hz. Muhammed'e iman eden Abdullâh b. Selâm ve arkadaşları kastedilmiştir. ${ }^{121}$ Surenin 14. ayetinde geçen şeytanlar ifadesiyle kastedilenler ise "Yahudilerin reisleri olan Kâb b. el-Eşref ve arkadaşları" dır. ${ }^{122}$ Tefsir rivayetlerinde birçok ayet bu grup Yahudilerle ilişkilendirilmiştir.

Uzeyr'in Allah'ın oğlu olduğunu söyleyenler ${ }^{123}$ de Sellâm b. Mişkem, Numân b. Evfâ, Ebû Enes, Şa's b. Kays, Mâlik b. es-Sayf ve Finhâs gibi Medineli bir grup Yahudidir. Onlar Hz. Peygamber'e “Sen bizim kıblemizi bırakmışken ve Uzeyr'in Allah'ın oğlu olduğunu kabul etmezken sana nasıl tabi olalım?" sözleriyle karşı koymuşlardır. ${ }^{124}$

Ayrıca Arapların önde gelenlerinden Abdullâh b. Ubey gibi söz konusu Yahudileri Hz. Muhammed aleyhine destekleyen ikiyüzlü kişilerin tutumlarıyla ilgili ayetler gelmiştir. ${ }^{125}$ Örneğin Ehl-i Kitab'1 dost edinmemeyi salık veren ayetler bu bağlamda nâzil olmuştur. ${ }^{126}$

Kur'an'da genellikle ilk gruba ilişkin ifadelerin devamında istisna edilerek ve övgüyle zikredilen ikinci grup Yahudiler, "Yahudilerden/Ehl-i Kitap'tan bazıları, çok azı" gibi tanımlamalarla geçen, Tevrat'ı iyi bilen, Hz. Muhammed'i ve getirdiği mesajı anlayan, ona iman edip tabi olan, bu nedenle birinci gruptaki kişiler tarafından

\footnotetext{
119 Mukâtil, Tefsîr, II/319.

120 Taberî, Câmiu'l-Beyân, I/258.

121 Mukâtil, Tefsîr, I/81; İbn Kesîr, Tefsîr, I/170.

122 Mukâtil, Tefsîr, I/91.

123 Tevbe, 9/30.

124 Taberî, Câmiu'l-Beyân, XI/409.

125 Bakara, 2/14; Mucâdele, 58/7-10; 14-20.

126 Bakara, 2/120; Âli İmrân, 3/118-120; Mâide, 5/41, 51-53, 57.
} 
topluluklarından dışlanmış kimselerdir. Bu grubun müşahhas örneği Abdullâh $b$. Selâm'dır. Birçok ayetin tefsirinde onlardan Abdullâh b. Selâm ve arkadaşları şeklinde söz edilirken, bazılarında isimler zikredilmektedir. Örneğin ataları İsrailoğulları'ndan alınan misaktan, diğer bir deyişle kitaplarında belirtilen temel düsturlara riayet etmeyen Yahudilerden söz edilen el-Bakara suresi 83. ayette pek azınız dışında ifadesiyle istisna edilenler isimleriyle zikredilmiştir. Bunlar, İ̉n Selâm, Sellâm b. Kays, Salebe b. Selâm, İbn Selâm'ın yeğeni Kays, Kâb'ın oğulları Esed ve Esîd, Yâmîn b. Yâmîn'dir. Onların Ehl-i Tevrat'ın müminleri olduğu söylenmiştir. ${ }^{127}$ Kaynukaoğulları Yahudilerinden Abdullâh b. Selâm ile birlikte akrabaları ve arkadaşlarından oluşan dokuz, Nadiroğulları'ndan üç, Kurayzaoguulları'ndan ise on bir kişinin ismi Müslüman olanlar arasında tespit edilmiştir. ${ }^{128}$ Bir görüşe göre İslam dünyasında yaşayan Yahudiler Hiristiyanlardan daha yüksek bir oranla Müslüman ol-

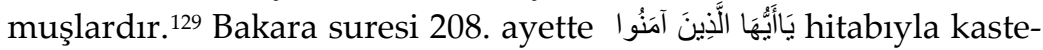
dilenler Hz. Muhammed'e iman Abdullâh b. Selâm'ın içlerinde olduğu gruptur. Onlar Müslüman oldukları halde Yahudi şeriatını tamamen bırakmamış, Cumartesi yasağını uygulamaya ve namazlarında yahut geceleri Tevrat okumaya devam etmek istemişlerdir. Bunun üzerine 208-209. ayetler nazil olmuş, kendilerine tam anlamıla İslam'ı benimsemeleri emredilmiştir. Bir diğer görüşe göre ise iman edenlerle birlikte Yahudilerin tamamı İslam'a davet edilmiştir. ${ }^{130}$

Müfessirlere göre Kur'an'da iki ayette geçen الرَاسبخُونَ فِي الْعَلِِْ ifadesiyle İbn Selâm ve yanındaki mühtediler kastedilmiştir. Mukâtil, ifadeyi Âli İmrân suresi 7. ayetin tefsirinde "Ehl-i Tevrat'tan iman eden Abdullâh b. Selâm ve arkadaşları gibi Tevrat ilmini iyice tedris etmiş olanlar"; Nisâ 162. ayetin tefsirinde "Yahudilerden Tevrat ilmini tedris etmiş olan Abdullâh b. Selâm ve arkadaşları" olarak açıklamıştır. İbn Abbâs'a göre de bu ifade ile Abdullâh b. Selâm, Useyd b. Saye ve Salebe b. Saye kastedilmektedir. Bu ayetin öncesinde Yahudilerin Hz. İsa ile ilgili yanlış kanaatleri, bazı temiz gıdaların kendilerine haram kılınmasına sebep teşkil

127 Mukâtil, Tefsîr, I/120.

128 Arslantaş, Hz. Muhammed Döneminde Yahudiler, 273-275.

129 Firestone, "İslam'ın Teşekkül Döneminde Yahudi Kültürü", 215.

130 Bk. Taberî, Câmiu'l-Beyân, III/599-604.

131 Âli İmrân, 3/7; Nisâ, 4/162. 
eden ribâ vb. haksız yollarla insanların mallarını yemeleri gibi yanlış tutumları üzerinde durulmuş; bu ayette ise ilim sahipleri ve müminler bu kınamadan istisna edilmişlerdir. Onların $\mathrm{Hz}$. Muhammed'e ve önceki peygamberlere indirilene iman ettikleri, namaz kılıp zekât verdikleri ve ahiret gününe inandıkları belirtilmiştir. Tevrat'1 iyi bilen bu kimselerin iman etmiş olmalarına rağmen ayette ilimde râsih olanlar ve mü'minler şeklinde ikili bir ifade mevcuttur. Buradaki mü 'minler ifadesi, Hz. Muhammed'in yanında olanlar anlamında toplumsal bir kategoriye işaret ediyor olmalıdır. Nitekim Mukâtil bu ifadeyi "Ehl-i Kitap'tan olmayan Muhammed'in ashabı" şeklinde açıklamıştır. ${ }^{132}$

Ayrıca onlar kendilerine verilmiş olan kitabı (Tevrat'ı) gereği gibi okuyup ona iman eden kimseler olarak tanımlanmışlardır. ${ }^{133}$ Ayette geçen kendilerine gönderilen kitabı gereği gibi okurlar ifadesini müfessirler ittifak halinde "helalini helal, haramını haram sayarak, kelimelerini anlamları dışına çıkarmayarak (tahrif etmeyerek), onları uygun olmayan şekilde yorumlamayarak o kitaba hakkıyla uyarlar" şeklinde açıklamışlardır. ${ }^{134} \mathrm{~Hz}$. Muhammed'e Kur'an'ın indirilişinden dolayı sevinirler ve ona iman ederler. ${ }^{135}$ Onlar kendilerine verilen emaneti hassasiyetle korurlar. ${ }^{136}$ Geceleri kalkip Allah'ın ayetlerini okuyarak secdeye kapanırlar. Onlar Allah'a ve ahirete samimiyetle inanırlar, iyiliği teşvik edip kötülüğe engel olmaya çalışırlar, hayır işlerine koşarlar. Onlar salihlerdir ve yaptıkları iyilikler karşılıksız kalmayacaktır. Allah onların kendisine karşı gelmekten sakındıklarını bilir. ${ }^{137}$ Tevrat'a inandıkları gibi Kur'an'a da inanırlar, Allah'a derinden bir saygiyla inanırlar, Yahudi reislerinin yaptığı gibi Allah'ın ayetlerini dünyalık menfaatle değişmezler. Onların Rableri katında mükâfatları vardır. ${ }^{138}$ Kitaba (Tevrat'a) sımsıkı sarılıp namazı kılan bu kimselerin yaptıkları iyilikler zayi edilmeyecektir. ${ }^{139}$

Ehl-i Kitap'tan, özellikle Medine Yahudilerinden Allah'a gönülden bağlanıp, O'nun koyduğu sınırları aşmayanlarla ilgili bu

\footnotetext{
132 Mukâtil, Tefsîr, I/264; 422; Suyûtî, ed-Durru'l-Mensûr, V/127.

133 Bakara, 2/121.

134 Mukâtil, Tefsîr, I/135; Taberî, Câmiu'l-Beyân, II/486-490.

135 Rad, 13/36; Ankebût, 29/47.

136 Âli İmrân, 3/75.

137 Âli İmrân, 3/113-115; bk. Mukâtil, Tefsîr, I/296.

138 Âli İmrân, 3/199; bk. Mukâtil, Tefsîr, I/323-324.

139 A'râf, 7/170; bk. Mukâtil, Tefsîr, II/72.
} 
ayetler, eş zamanlı nâzil oldukları diğer ayetlerle birlikte okunup bağlamları içerisinde değerlendirildiğinde Yahudilerin homojen bir grup olmadığı görülmektedir. Bu ayetlerin öncesinde genellikle dinlerine yabancılaşmış olanlardan söz edilirken, bu ayetlerle Allah'ın iman ve davranışlarını onayladıkları istisna edilmiştir. Ayetlerden biri kısaca değerlendirilecektir.

Kitap ehlinden öylesi vardır ki, ona yüklerle mal emanet etsen, onu sana (eksiksiz) iade eder. Fakat onlardan öylesi de vardır ki, ona bir dinar emanet etsen, tepesine dikilip durmadıkça onu sana iade etmez. Bu da onların, "Ümmîlere karşı bize vebal yoktur" demelerinden dolayıdır. Onlar, bile bile Allah'a karşı yalan söylerler. ${ }^{140}$

İbn Abbâs ve İbn Cureyc'den (ö.150/767) nakledildiğine göre, Yahudilerden bazıları bazı Araplarla veresiye alışveriş yapmış, Araplar Müslüman olduktan sonra satışları karşılığında alacakları parayı Yahudilerden istediklerinde onlar "sizin bizde emanetiniz yoktur, çünkü siz dininizi terk ettiniz, kitabımız Tevrat'ta bu böyledir" demişlerdir. Buna göre emanetleri vermemelerinin sebebi Müslümanları dinlerini değiştiren kişiler saymaları ve Tevrat'ta dinini değiştirenlerin mallarına el konulmasının caiz olduğunun bildirilmiş olmasıdır. Bir süre sonra benzeri bir tavrı bazı Müslümanların gösterdiği rivayet edilmiştir. Bir adam İbn Abbâs'a "bunda bir mahzur görmüyoruz" diyerek zımmîlerden bazı şeyler aldıklarını, bu yaptıklarının doğru olup olmadığını sormuş, İbn Abbâs ona "bu yaptığınız Ehl-i Kitab'ın ümmîlere karşı sorumluluğumuz yoktur' demelerine benziyor. Ehl-i Kitab cizyeyi verdikleri sürece onların malları size helal değildir" cevabını vermiştir. ${ }^{141}$ Medine'de Yahudi olmayanlardan aldıkları malları iade etmeyen bazı Yahudiler bu davranışlarını Tevrat'a dayandırmışlardır. Ayette Yahudilerin ümmîlere karşı bize bir vebal yoktur; -tefsirlere göre- "Tevrat'ta böyle yazıyor" diyerek kendilerini temize çıkardıkları söylenmiştir. Bunun üzerine ayette onlarm bilerek yalan söyledikleri ifade edilmiştir.

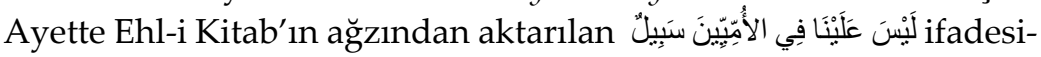
nin izini Yahudi kaynaklarından süren Yasin Meral, ifadenin arka planını Rabbânî literatür içerisinde tespit etmiştir. Yahudi olmayan biri, Yahudilerin malını çalamaz, gasp edemez ve savaş sonunda ka-

\footnotetext{
140 Âli İmrân, 3/75.

141 Taberî, Câmiu'l-Beyân, V/512-513.
} 
Erken Dönem Kur’an Tefsirlerine Göre Medine Yahudileri...

dınlarını eş olarak alamaz. Fakat bir Yahudinin, Yahudi olmayanların malını çalması, gasp etmesi ve bir savaş sonunda kadınlarını eş olarak alması caizdir. ${ }^{142}$ Fakat aynı literatür içerisinde bu uygulamaya yapılan itirazlar kayda alınmış ve bazı rabbiler tarafından uygulama kısmen yasaklanmıştır. Roma yönetimi Yahudi dini ve kültürü hakkında bilgi edinmek için Rabban Gamaliel'e iki devlet görevlisi göndermiştir. Görevliler Tevrat, Mişna, Gemara, Halaha ve Agada gibi Yahudi dini literatürünün temel kaynaklarını öğrendikten sonra iki husus haricinde Yahudi dini sisteminin övgüye değer olduğunu söylemişlerdir. İtiraz ettikleri iki husustan biri, Yahudi bir kadın Yahudi olmayan bir kadına doğum yaptıramazken, Yahudi olmayan bir kadının Yahudi bir kadına doğum yaptırabilmesi ve Yahudi bir kadın Yahudi olmayan birisinin çocuğunu emziremezken, Yahudi olmayan bir kadının annesinin izniyle bir Yahudi çocuğu emzirebilmesidir. İkincisi, başkalarının Yahudi'nin malını gasp etmesi yasak edilmişken, Yahudi'nin Yahudi olmayanların malını gasp etmesinin caiz görülmesidir. Bunun üzerine Rabban Gamliel, Yahudi olmayanlardan bir şey çalmayı 'Tanrı'ya saygısızlık' olarak değerlendirip yasaklandığını hükme bağlamıştır. Buna göre Yahudi olmayanların mallarını gasp eden Medineli Yahudilerin Rabbânî literatürdeki eski hükmü; söz konusu malları emanet bilinciyle iade edenlerin ise Rabbi Gamaliel'in ictihâdını esas aldıkları ve Kur'an'ın bu yaklaşımı onayladığı söylenebilir. ${ }^{143}$

Medine Yahudilerinin Rabbânî kaynakları "Tevrat" olarak niteledikleri ve uygulamada bu kaynaklardaki farklı içtihatlara tabi olabildikleri bu örnekte de görülebilmektedir. Kur'an ise onların bu uygulamalarından bazılarını reddederken bazılarını onaylamakta, dolayısıyla Rabbânî kaynaklardaki içtihatlar arasında eleme yapmaktadir.

Medine Yahudileri arasında üçüncü grup ise yeterli Tevrat bilgisine sahip olmayıp bilenlere tabi olan Yahudi halkıdır. Çıkarları

142 Yasin Meral, "Leyse Aleynâ fi'l-Ümmiyyîne Sebîl", MAÜIBFD 1/2 (Mardin: 2014): 165-166. Savaş sonrası kadınlara el konulması ise Tora'ya dayanmaktadır: Tesniye, 21: 10-14.

143 Meral, “Leyse Aleynâ fi'l-Ümmiyyîne Sebîl”, 165-169. 
yahut vicdanları doğrultusunda dâhil oldukları topluluğa ve onların tutumlarına göre muamele görmüşlerdir. ${ }^{144} \mathrm{~Hz}$. Muhammed'le anlaşmalarını bozmayan Yahudiler Medine'de Müslümanlarla birlikte yaşamaya devam etmişlerdir. Hz. Peygamber vefat ettiğinde Medine'de Kurayzaoğulları'ndan bazı tüccar Yahudilerin bulunduğu belirtilmiştir. Bunlar kabilelerinin ihanetine itiraz etmiş ve onlardan ayrılmışlardır. Ayrıca Medine'de Müslümanları Hayber seferinden vazgeçirmeye çalışan Yahudilerden söz edilmiştir. Bununla birlikte Müslümanlara destek olup bilfiil Hayber Yahudilerine karşı Müslümanların yanında sefere katılan Yahudiler olmuştur. Hz. Peygamber'in savaş sonrası bu Yahudilere ganimetten pay verdiği söylenmiştir. Tebûk seferine katılmak isteyen Yahudilerden de söz edilmiştir. Hz. Peygamber ve sahabenin Yahudi komşularıyla kurduğu dostça ilişkilere dair çeşitli örnekler mevcuttur. ${ }^{145}$ İbn Abbâs ve Katâde' den bildirildiğine göre sahabeden baz1larının Hz. Peygamber'e Kurayza ve Nadiroğulları'ndan olan akraba ve yakınlarına sadaka verip veremeyeceklerini sormaları üzerine el-Bakara suresi 272. ayet nâzil olmuş ve Hz. Peygamber Yahudi yakınlarına sadaka verebileceklerini söylemiştir. ${ }^{146}$ Saîd b. Cubeyr'in (ö. 94/713) bildirdiğine göre daha önce zımmîlere sadaka veren sahabe, Müslüman fakirler çoğalınca, sadakalarını zımmîlere vermeyip Müslümanlara vereceklerini söylemişler, söz konusu ayet bunun üzerine nâzil olmuştur. ${ }^{147}$

Ehl-i Kitab'ın yemeği Müslümanlara, Müslümanlarınki Ehl-i Kitab'a helal kılınmıştır. Ehl-i Kitab kadınları ile evlenmek helaldir. ${ }^{148}$ İbn Abbâs, Ebu Umâme (ö. 86/705), Mucâhid, Saîd b. Cubeyr, İkrime, Hasen el-Basrî, Mekhûl (ö. 112/730), İbrâhim en-Nehaî (ö. 96/714), Suddî, Mukâtil b. Hayyân (ö. 150/767) ve Mukâtil b. Süleymân'dan aktarıldığına göre ayetteki طَعَ'dan kasıt Ehl-i Kitab’ın kestiği hayvanlardır. Ehl-i Kitap onları Allah'tan başkası adına kesmeyi haram saymakta ve Allah'ın adını anarak kesmektedirler. İbn

\footnotetext{
144 Bakara, 2/78; Müslümanlarla ilişkileriyle ilgili olarak Yahudilerin kendi içlerindeki çatışmaya, farklı tutumlarına dair örneğin bk. Bakara, 2/75-82; A râf:, 7/168170 .

145 Arslantaş, Hz. Muhammed Döneminde Yahudiler, 270-272.

146 Taberî, Câmiu'l-Beyân, V/20.

147 Suyûtî, ed-Durru'l-Mensûr, III/332.

148 Mâide, 5/5.
} 
Kesîr, Mâlikîlerin bu ayete dayanarak Yahudilere haram kılınan yağ ve benzeri şeyleri yemeyi haram saydıklarını belirtmiştir. ${ }^{149}$

Kur'an sık sık uyacakları ilkeler konusunda İsrailoğulları'ndan alınan sözü Medine Yahudilerine hatırlatmaktadır. Kur'an'ın hatırlattığı bu ilkelere uyup uymamalarının kabaca yaptığımız gruplandırmada onların yerlerini belirleyen temel etken olduğu söylenebilir. Örneğin el-Bakara suresi 83. ayette Allah, İsrailoğulları'ndan kendisinden başkasına ibadet etmemeleri, ana-babaya, yakınlara, yetimlere, yoksullara iyilik etmeleri, güzel (doğru) söz söylemeleri, namazlarını kılıp zekâtlarını vermeleri üzerine söz aldığını, fakat bu konuda çok azı hariç sözlerinde durmadıklarını hatırlatmıştır. ${ }^{150}$ Ayette hariçte tutulanlar Ehli Tevrat'tan iman eden İbn Selâm, Sellâm b. Kays, Salebe b. Selâm, İbn Selâm'ın yeğeni Kays, Kab'ın oğulları Esîd ile Esed ve Yâmîn ile onun oğludur. ${ }^{151}$ Medine Yahudilerinin büyük bir kısmı Evs ve Hazrec arasındaki çatışmalara katılarak, bunun kendileri için yasaklanmış olduğunu bile bile, birbirlerinin kanını dökmüşlerdir. Bu bağlamda Allah el- Bakara suresi 84. ayette birbirlerinin kanını dökmeme ve birbirlerini yurtlarından çıkarmamaları hususunda İsrailoğulları'ndan kesin söz aldığını ve onların bunu kabul ettiklerini hatırlatmış, Medine Yahudilerininse bu bilgiye sahip olduklarını söylemiştir. ${ }^{152}$

Medine'de Müslüman, Yahudi ve Hıristiyanlardan bazılarının birbirlerine karşı sadece kendilerinin doğru yolda ve Allah'a daha yakın olduklarını iddia etmeleri üzerine Allah Nisâ suresi 123-125. ayetleri indirmiştir: ${ }^{153}$ Onların bu iddiaları kendi kuruntularıdır. Kötülük yapanlar cezalandırılacak, salih amel işleyen müminler ise cennete girecek ve herhangi bir haksızlığa uğramayacaklardır. Dini en güzel olanlar tüm samimiyetiyle Allah'a teslim olup Hanif olarak İbrâhim'in dinine uyanlardır. Allah İbrâhim'i dost edinmiştir. Böylece Hz. Mûsâ, Hz. Îsâ, Hz. Muhammed ve dinlerini aralarındaki polemiğin konusu yapıp yarıştıranlara, polemiğin dışından, hepsinin kabul ettiği bir peygamber ve tevhid dininin üstünlügü ile cevap verilmiştir.

\footnotetext{
149 İbn Kesîr, Tefsir, III/40.

150 Benzer şekilde İsrâ suresinin 22-38. ayetleriyle Sina dağında Hz. Mûsâ'ya verilen on emir hatırlatılmıştır. Krş. Çıkış, 20: 2-17; Tesniye, 5: 6-21.

151 Mukâtil, Tefsir, I/120.

152 Taberî, Câmiu'l-Beyân, II/207-215.

153 Taberî, Câmiu'l-Beyân, VII/507-511.
} 


\section{Sonuç}

Tarihi verilere göre Medine' ye Araplardan önce yerleşen Yahudiler, bölgede gerek ekonomik gerekse kitaplı ve okullu bir topluluk olmalarıyla kültürel yönden etkin olmuşlardır. Erken dönemde Yahudiler ve Müslümanların "Tevrat" olarak isimlendirdikleri metinlerin Tora'nın yanı sıra Tanah'ın bütününü, Rabbânî ve hatta kanonik olmayan bazı metinleri kapsadığı düşünülmektedir. Kur'an'ın Yahudilerle ilgili atıfları ile bunların erken dönem yorumları birlikte değerlendirildiğinde Medine Yahudilerinin Rabbânî geleneğin takipçileri oldukları görülmektedir. Bununla birlikte onların homojen bir topluluk olmadıkları söylemek gerekir.

Kur'an ile Hz. Peygamber'in Medine ve çevresindeki Yahudilere gösterdiği ilgi oldukça yoğundur. Bununla birlikte Kur'an ayetlerinin Yahudilerle ilgili olumlu/olumsuz genelleyici bir yaklaşımı bulunduğu söylenemez. Hz. Muhammed'in peygamberliğinden önce İsrailoğulları'ndan Allah'a verdikleri ahdi bozanlar olduğu gibi bu ahde sadık kalanlar olmuştur. Benzer şekilde Medine'de Hz. Muhammed'le yaptıkları, şehrin ortak çıkar ve değerlerinin korunmasına yönelik sosyo-ekonomik anlaşmalarını bozan Yahudiler olduğu gibi az sayıda olsa da devam ettirenler olmuştur. Gerek Mekke gerekse Medine konjonktürü, Yahudilerle ilişkiler bağlaminda Kur'an ayetlerinin gelişinde arka plan oluşturmuştur. Kur'an Medine'nin en fazla nüfusa sahip topluluğu Yahudileri vahyin Mekke dönemi ortalarından itibaren muhatap almıştır. Yahudilerle ilişkilerin yoğunlaştığı hicret sonrası ilk birkaç yıl Yahudiler bağlaminda gelen ayetlerin de çoğaldığı yıllardır. Yahudilerin gerek Hz. Peygamber'in daveti karşısındaki gerekse siyasi tutumlarının kendileri ile ilgili nâzil olan vahyin, dolayısıyla Hz. Peygamber'in yaklaşımı üzerinde belirleyici olduğu söylenebilir. Vahyin dilini etkileyen bu arka planla birlikte ayetlerin genel teması Hz. Muhammed'le kendisinden önce gönderilen peygamberlerin getirdikleri tevhit dininin aynı olduğudur. İnsanlardan, Allah'a ortak koşmaksızın kul olmakla birlikte peygamberlerinin getirdikleri ilkelere tabi olmaları istenmiştir. Bu ilkeler, gelen her peygamberle, son olarak da Hz. Muhammed'le hatırlatılmıştır.

\section{Kaynakça}

Arslantaş, Nuh. Medine Döneminde Yahudiler. İstanbul: Kuramer Yayınları, 2016. 
Erken Dönem Kur’an Tefsirlerine Göre Medine Yahudileri...

Besalel, Yusuf. Yahudilik Ansiklopedisi. 3c., İstanbul: Gözlem Gazetecilik Basin ve Yayin A.Ş., 2001-2002.

Cilacı, Osman. “Ahbâr". DİA. c. I (1988): 485-486.

Döner, Ertuğrul. Tefsirde İsrâiliyyât'ın Kaynak ve Bilgi Değeri. Ankara: Ankara Okulu Yayınları, 2017.

Gürkan, Salime Leyla. “Rabbâniyyûn”. DİA. c. XXXIV (2007): 376-377.

Haleva, Rav Naftali (haz.). Pirke Avot. İstanbul: Gözlem Gazetecilik Basın ve Yayın A.Ş., 2004.

Hamidullah, Muhammed. İslam Peygamberi. Çev. Salih Tuğ. Yeni Şafak, Ankara, 2003.

Horovitz, J. İslami Tarihçiliğin Doğuşu. Çev. Ramazan Altınay, Ramazan Özmen. Ankara: Ankara Okulu Yayınları, 2002.

İbn Ebî Hâtim, Abdurrahmân b. Muhammed er-Râzî (ö. 327/938). Tefsîru'lKur'ân'il-Azîm. Thk. Es'ad Muhammed Tayyib, 10 c. Mektebetü Nezâr Mustafâ el-Bâz, el-Memleketü'l-Arabiyyeti's-Suûdiyye, h. 1419.

İbn İshâk, Ebû Abdillâh Muhammed b. İshâk (ö. 151/768). Siyer. Çev. Sezai Özel. İstanbul: Akabe Yayınları, 1991.

İbn Kesîr, İsmâil b. Umer (ö. 774/1373). Tefsîru'l-Kur'âni'l-Azîm. Thk. Sâmi b. Muhammed Selâme, Dâru't-Tayyibe, 1999.

İbn Sad, Ebû Abdillâh Muhammed (ö. 230/845). Kitâbu't-Tabakâti'l-Kebîr. 10 c., Thk. Alî Muhammed Umer, Kahire: Mektebetu'l-Hancî, 2001.

Jacobs, Joseph. "Cohen", The Jewish Encyclopedia (JE). 4 c. (New York and London: 1903).

Katsh, Abraham Isaac. Judaism in Islam: Biblical and Talmudic Backgrounds of the Koran and Its Commentaries. New York University Press, 1954.

Kutubu's-Sitte. 23c., İstanbul: Çağrı Yayınları, 1992.

Mazuz, Haggai. The Religious and Spiritual Life of the Jews of Medina. LeidenBoston: Brill, 2014.

Meral, Yasin. "Leyse Aleynâ fi'l-Ümmiyyîne Sebîl”. Artuklu Akademi 1/2 (Mardin: 2014): 165-169.

The Mishnah. Haz. Herbert Danby. Oxford University Press, 1933.

Mukâtil b. Suleymân, Ebû'l-Hasen b. Beşîr el-Ezdî el-Belhî (ö.150/767). Tefsîru Mukâtil b. Suleymân. Thk. Abdullâh Mahmûd Şehâte. Beyrût: Dâru İhyâi't-Turâs, 2002.

Paçacı, Mehmet. Çă̆daş Dönemde Kur'an'a ve Tefsire Ne Oldu?. İstanbul: Klasik Yayınları, 2008.

Semhûdî, Ebû'l-Hasen Alî b. Abdillâh b. Ahmed (ö.911/1505). Vefâu'l-Vefâ bi-Ahbâri Dâri'l-Mustafâ. 5 c., Thk. Kâsım Samerrâ'î. Mekke-Medine: Muessesetu'l-Furkân li't-Turâsi'l-İslâmî (London: al-Furqan Islamic Heritage Foundation), 2001.

Es-Suyûtî, Ebû'l-Fadl Celâluddîn (ö. 911/1505). Ed-Durru'l-Mensûr fi't-Tefsîr bi'l-Me'sûr. 17 c., Thk. Abdullâh bin Abdulmuhsin et-Turkî. Kahire: Merkezu'l-Buhûs ve'd-Dirâsâti'l-Arabiyyeti ve'l-İslâmiyyeti, 2003. 
Bedrige YULMAZ

Et-Taberî, Ebû Cafer Muhammed b. Cerîr (ö.310/923). Câmiu'l-Beyân an Te'vîli-Âyi'l-Kur'ân. 26 c., Thk. Abdullâh bin Abdulmuhsin et-Turkî. Kahire: Merkezu'l-Buhûs ve'd-Dirâsâti'l-Arabiyyeti ve'l-İslâmiyyeti, 2001.

Talmud, Bavli. The Schottenstein Edition. 72 c. Mesorah Publications, 20082009.

Talmud, The Jerusalem. Massachusetts: Hendrickson Puplisher, 2008.

Tora: Türkçe Çeviri ve Açıklamalarıyla. Çev. Moşe Farsi ve dğr., 5 c. İstanbul: Gözlem Gazetecilik Basın ve Yayın A.Ş., 2002-2009. 